\title{
Enron: The Smartest Guys in the Room-Using the Enron Film to Examine Student Attitudes towards Business Ethics
}

\author{
Pamela L. Cox \\ Barry A. Friedman \\ Ann-Lorraine Edwards \\ State University of New York at Oswego
}

\begin{abstract}
Publicity from recent scandals has generated increased discussion of the role of business schools in teaching students about ethical behavior. The business ethics literature reveals that business schools can be effective in changing student attitudes towards business ethics. The approach used in this research integrates the teaching of business ethics into an undergraduate organizational behavior course. We outline the use of the film Enron: The Smartest Guys in the Room as an intervention to engage student discussion about their attitudes towards business ethics. We report an assessment of the effectiveness of the intervention, and provide suggestions for future research.
\end{abstract}

\section{Introduction}

Recent media attention focused on high profile cases like Enron, Adelphia Communications, WorldCom, and other corporations indicate that high risk taking behavior by top management can rapidly evolve into allegations of corporate fraud committed against company shareholders (Kidwell, Jr. \& Kochanowski, 2005, p. 136). Unethical behavior can affect organizational performance and is costly to employers, employees, shareholders, and other organizational stakeholders. The high publicity of recent scandals has generated increased discussion of the role of business schools in teaching students about ethical behavior in the workplace. The collapse of Anderson further emphasized the importance of workplace ethical conduct. That Anderson, among the oldest accounting firms, could so quickly lose its credibility has generated renewed professional self-examination (Molyneaux, 2004). If ethics considers the morality or rightness or wrongness of behavior in terms of organizational, legal, and societal guidelines (Robinson \& Bennett, 1995), then business ethics considers what constitutes moral behavior in the workplace. For the purposes of this research, our goal in the teaching of business ethics is to increase student awareness of ethical issues in the workplace.

Much of the discussion of the role of business schools in teaching business ethics has focused on whether or not the subject is appropriate for inclusion at both the undergraduate and graduate school levels. Some of the press covering the recent corporate and accounting scandals concludes business schools have not sufficiently revised their curricula to cover ethics (Earley \& Kelly, 2004). Others argue that ethics cannot be taught in the classroom, that one's upbringing largely determines individual behavior (Stape, 2002) or that ethical dilemmas should be addressed on the job rather 
than in a business classroom (Petrecca, 2002). Critics also suggest that ethics courses are sometimes created for the sake of appearances with courses providing little more than indoctrination resulting in students' inability to transfer their ethical skills into the business environment (McDonald \& Donleavy, 1995). It has also been suggested that the college socialization process may, in fact, be partially to blame for the failure of organizations to respond effectively to unethical behavior in the workplace. Kidwell, Jr. \& Kochanowski (2005, pp. 142-143) stated that:

A related roadblock to ethical behavior may be the socialization of the workforce to stay passive (withhold effort) when unethical (and illegal) behaviors should be brought to light. One potential concern is that the socialization process that students undergo in college fosters such passive reactions among future managers. Recent corporate and government scandals took many months, and in some cases years to emerge because of the reluctance of organizational members to blow the whistle. Aside from potential financial losses, managers may fear being labeled as deviants, and such labeling may start or be reinforced in college. Some professors do not tolerate dissent and fail to encourage student challenges to the prevailing orthodoxy. Negative outcomes can also result when students who do not want to be considered deviants do not report their classmates who cheat on tests or plagiarize papers.

Notwithstanding the criticisms of the efficacy of incorporating the teaching of business ethics into the business classroom, the corporate workplace and increased business regulation does not seem to be effective in preventing unethical behavior. Koehn (2005) contended that we should not give up on our students even if the message that students and employees seem to be hearing in the workplace is one that encourages selfishness or greed. He cited the government failure to regulate behavior so that it complies with law is due to the human tendency to game the system. He further stated: "What is needed are radical changes in people's self-conceptions. It is our duty as teachers to try to bring about positive change in our students" (p. 141). While Koehn discusses government failure to regulate ethical behavior, in reality, governments are only able to regulate legal behavior. Koehn also does not discuss the nature of the positive change teachers should bring about in their students. For example, should teachers ask students to adopt a certain value system or facilitate discussion of differing value systems and then let students make up their own minds?

The business ethics literature reveals that business schools can be effective in changing student awareness of and attitudes toward business ethics. Research suggests that moral development continues during the college years and that college education can be positively associated with moral development (King \& Mayhew, 2002; Williams \& Dewett, 2005). Williams \& Dewett's 2005 review of the business ethics literature indicated that business ethics education can be effective in increasing students' awareness of moral issues, promoting students' moral development, and promoting students' ability to handle complex ethical decision making. Research has also linked business ethics education with changing student attitudes towards business ethics. Ethics education may contribute to the evolution of student attitudes from 
skepticism to an enhanced understanding of the scope of ethical issues and the complexity of ethical decision making (MacFarlane, 2001).

A survey of 239 deans attending the AACSB 2003 Dean's Conference indicated that the majority of business schools integrate ethics and corporate social responsibility into the business curriculum, rather than using a stand-alone course (McDonald, 2004). Use of a stand-alone ethics course, especially one taught outside the business curriculum, has been criticized for giving students the wrong impression of the business world by separating the consideration of ethical dilemmas from their real world business consequences (McDonald, 2004, p. 373).

The approach used in this research integrates the teaching of business ethics into an undergraduate organizational behavior course. Our intent in teaching students about business ethics is not to take a position of what specific behaviors are ethical and which are not, but rather to instill in students an awareness of situations in the workplace that have ethical implications. We outline the use of the film Enron: The Smartest Guys in the Room (Magnolia, 2005) as an instrument to increase students' awareness of ethical issues and engage student discussion about their attitudes towards business ethics. We report a quantitative and qualitative assessment of the effectiveness of the intervention on student attitudes, and provide suggestions for future research.

\section{Literature Review}

\section{Goals for Business Ethics Education}

Goals of business ethics education have included the teaching of ethical theory and the particular contexts unique to making ethical decisions in the workplace (Morse, 1999). The objective of some courses is to have an effect on student awareness of ethical issues and attitudes towards ethics, while other courses focus on reasoning ability, with a third type of course seeking to integrate the two objectives of awareness and reasoning (McDonald, 2004). Williams \& Dewett (2005) contend that business ethics education should promote students' moral development since moral development is related to the recognition of ethical dilemmas. Goals that have been suggested for business ethics courses include stimulating moral imagination (Callahan,1980), recognizing ethical issues in the workplace (Callahan, 1980; Gautschi, III \& Jones, 1998; Sims \& Sims, 1991), eliciting a sense of moral obligation (Callahan, 1980; Williams \& Dewett, 2005), developing moral reasoning skills (Sims \& Sims, 1991; Thorne \& Hartwick, 2001) developing analytical skills, tolerating and reducing disagreement and ambiguity (Callahan, 1980), and integrating managerial competence with moral competence (Powers \& Vogel, 1980, Schwartz, Kassem, \& Ludwig, 1991).

\section{$\underline{\text { Teaching Business Ethics }}$}

One of the most challenging problems facing business professors is developing techniques for teaching business ethics that truly engage the student. Anecdotal evidence indicates that classroom discussion about ethics is richest when students 
seem most interested in the subject matter (Haywood, McMullen, \& Wygal, 2004). There is some evidence that today's generation of students may, in fact, have a low threshold for boredom and a high need for action (Faust, Ginno, Laherty, \& Manuel, 2001). Other research indicates that students learn more and retain more when they are active participants rather than just listening to lectures (Pascarella \& Terenzini, 1991). High engagement methods used by business professors to teach business ethics include the use of parables (Koehn, 2005), debate (Koehn, 2005), role plays (Brown, 1994, McPhail, 2002), video and film (Earley \& Kelly, 2004, McPhail, 2002), case studies and discussion (Earley \& Kelly, 2004, Kidwell, Jr. \& Kochanowski, 2005, McPhail, 2002; Molyneaux, 2004), poetry (McPhail, 2002), peer discussion (Thorne \& Hartwick, 2001), and an ethics bingo game (Haywood, McMullen, \& Wygal, 2004). Gautschi, III and Jones (1998) argue that student exposure to ethical issues through the use of case study and discussion can increase the salience and vividness of moral issues, thereby enhancing the ability of students to recognize ethical issues. They further contend that "although not a sufficient condition for ensuring ethical behavior, ethical awareness qualifies as a precondition to such behavior" (p. 208). The authors found that students who were exposed to ethics education recognized ethical issues more readily than students that were not.

\section{$\underline{\text { Research Measuring Ethics Education Effectiveness }}$}

While much of the literature on ethics education does not attempt to assess program effectiveness beyond providing anecdotal evidence, an increasing number of studies have attempted to quantitatively assess the effectiveness of business ethics education using a variety of methods. Gautschi and Jones (1998) used an experimental and a control group to test the efficacy of an ethics course in increasing student awareness of ethical issues. Students in the experimental group were enrolled in a course designed to increase the saliency of ethical issues in business. Students in the control group were enrolled in a marketing course with no business ethics component. At the beginning of the semester, students in both conditions were asked to read vignettes about corporate culture and list reasons why they might like to work in such an environment. At the end of the semester, students completed the same exercise with a second vignette. Four raters "graded" the student responses by counting the number of ethical issues listed by each student. Students in the experimental group identified significantly more ethical issues after taking the ethics course than students in the control group.

Other studies have focused on promoting student moral development through business ethics education. Penn and Collier (1985) examined the moral development of MBA students before and after being exposed to business ethics education. At the beginning of the semester, no student demonstrated predominantly principled reasoning. By the end of the semester, $37 \%$ of the students had reached a principled reasoning level. Earley and Kelly (2004) found that exposure to ethics education in a semester-long auditing course resulted in an increase in students' context-specific moral reasoning. MacFarlane (2001) examined the use of learning logs to change student attitudes towards business ethics. During the semester, students enrolled in the course were asked to log their attitudes and opinions regarding business ethics. Content analysis of 
students' learning logs revealed an evolution from skepticism and relativist attitudes to an enhanced understanding of the scope and complexity of ethical issues and decision making.

\section{Research Examining the Use of the Enron Case}

Earley and Kelly (2004) assessed students' moral reasoning pre and post-Enron over two semesters: one occurring in 2001 (pre-Enron) and one occurring in 2002 (postEnron). Specifically they asked the question of whether there is an "Enron effect"-is ethics education more effective when it is studied in the context of the Enron/Andersen case and other recent accounting scandals. Both in 2001 and in 2002, students enrolled in an undergraduate accounting course were assessed at the beginning and the end of the semester using two measures of moral reasoning: context specific moral reasoning using the Accounting Ethical Dilemma Instrument (Thorne, 2000) and general moral reasoning using the Defining Issues Test (Rest, 1979). During both semesters students were exposed to a variety of curriculum interventions concerning business ethics: case studies, videos, and class discussion. The post-Enron group followed the same curriculum as the pre-Enron group, except that there was an emphasis on Enron and Andersen related issues. During both semesters there was a positive significant change on students' context specific moral reasoning scores but not in their general moral reasoning scores. When compared to the pre-Enron semester, there was no significant difference in change in moral reasoning scores in the semester where Enron and Andersen were emphasized. However, there was some anecdotal evidence that students may have been more interested in the class and more motivated in the postEnron semester. For example, course evaluation scores increased slightly during the post-Enron semester. However, the increase in course evaluation sources may have been due, in part, to a recency effect.

The research outlined in this study examines the effect of the film Enron: The Smartest Guys in the Room, the Hans Christian Andersen fairytale "The Emperors New Clothes" (available at www.mindfully.org/reform/Emperors-New-Clothes.htm), and related classroom discussion and homework assignments on student attitudes towards business ethics (see Appendix A). The Enron film, the Hans Christen Anderson fairytale and related classroom debriefing together constituted the experimental condition. As recommended by Gautschi and Jones (1998), we employed a research design comparing experimental and control groups.

\section{$\underline{\text { Research Hypothesis }}$}

$\mathrm{H} 1$ : Students in the experimental group will develop more positive attitudes towards the importance of ethical behavior in the workplace.

We hypothesize there will be a significant difference in ethics attitudes between the experimental group (subjects exposed to the Enron film and interventions) compared to those in the control group. If results support this hypothesis, it would indicate that exposure to an experiential learning intervention using the Enron video and subsequent 
facilitated discussion would result in a heightened awareness of ethical issues in the workplace and a subsequent change in attitudes towards ethics in business. If the teaching intervention affects attitudes, this would have powerful implications for business curriculum.

While Earley and Kelley (2004) emphasized Enron during their post-Enron semester, the film Enron: The Smartest Guys in the Room was not used. We felt that the use of the film would engage students in learning about business ethics and increase the saliency and vividness of ethical issues; thus increasing ethical awareness. Our reasoning follows Gautschi, III and Jones (1998) findings that the use of case study and discussion can increase the vividness of moral issues, thereby enhancing the ability of students to recognize ethical issues. Using a highly interesting and engaging film will increase the vividness of moral issues; thus, heightening student awareness of ethical issues in the workplace. Vividness of information is its capacity "to attract and hold attention and to excite imagination" (Nisbett \& Ross, 1980, p. 45). Information is vivid "to the extent that it is (a) emotionally interesting, (b) concrete and imagery-provoking, and (c) proximate in a sensory, temporal, or spatial way" (Nisbett \& Ross, 1980, p. 45). The researchers also maintain that vivid information has more judgmental impact than pallid information.

There is some evidence that visual images can enhance retention of learned information (Blanchard \& Thacker, 2005; Honeycutt et al, 1993), because visual images are more readily coded symbolically and recalled. The Enron film, with its creative use of popular music, cartoons like the Simpsons, news clips, and candid interviews, is emotionally interesting, imagery-provoking, and proximate in a sensory way. We hypothesize that the film will attract and hold the attention of students more substantially than less vivid methods of conveying information like, for example, lecturing. Increased attention should lead to increased awareness of ethical issues. Increased awareness of ethical issues will in turn result in a change in student attitudes towards business ethics.

\section{Method}

Fifty-seven undergraduate students from a Northeastern public university in the United States participated in the study. The students attended two sections of an undergraduate course entitled Organizational Behavior, a course that explores such topics as motivation, job satisfaction, leadership, power, conflict, communication, and change in the workplace. The sample was $56 \%$ male and $44 \%$ female. The largest age category was $21-25(79 \%)$, followed by $15-20(19 \%)$. The subjects' areas of concentration in the business degree program were business administration (49\%), human resource management (10\%), wellness management $(31 \%)$, and other $(8 \%)$. The sections did not differ with respect to gender $\left(?^{2}=.36,1 d f\right)$, major $\left(?^{2}=.60,3 d f\right)$, the extent that religion was practiced $\left(?^{2}=.42,2 d f\right)$, or ethic mindedness $\left(?^{2}=.34,2 d f\right)$. The control group was slightly younger than the experimental group $\left(?^{2}=5.99,2 d f, p \leq\right.$ $.05)$, with $7 \%$ between the ages of $15-20$ compared to $31 \%$ in the experimental group. 
All subjects responded to the "Attitude Towards Business Ethics Questionnaire" (ATBEQ) (see Appendix B). The original ATBEQ contained thirty items that measured respondents' attitudes towards various aspects of ethics within a business context using Stevens (1979) values clarification exercises (Moore \& Radloff, 1996; Small, 1992; Preble \& Reichel, 1988). To increase efficiency, Moore \& Radloff (1996) recommended that five items be removed from the questionnaire based on factor analysis results. After pre-testing the questionnaire with students, three additional items were dropped from the questionnaire based on students' lack of understanding. Each questionnaire item used a five point Likert rating scale, where 1 was "strongly disagree", 2 was "disagree", 3 was "not sure", 4 was "agree", and 5 was "strongly agree". The resultant questionnaire consisted of 22 items (Appendix B). The questionnaire also measured age, gender, major, the extent that students practiced religion, and ethic mindedness. The experimental and control groups should be equivalent with respect to their attitudes towards business ethics. Upon pre-testing, the two sections did not differ with respect to any of the 22 ATBEQ items (statistics may be obtained from the authors).

The Organizational Behavior course consisted of two sections with 28 and 29 students. The ATBEQ was administered to both sections at the beginning of the semester prior to any coverage of business ethics material (pretest). Following pretest administration of the ATBEQ, the experimental group sections were given a brief (20 minute) lecture on business ethics (Appendix C), the Enron film, discussion questions to answer outside of class as homework (see Appendix A), and an assignment to read "The Emperor's New Clothes" and compare the fairytale to the Enron case. We did not control for learner preconceived biases towards Enron. However, whatever biases existed would have been present for both sections. The control group received an unrelated lecture on motivation in the workplace while the other section of the class viewed the Enron video. The control group did not view the Enron film, read the Emperor's New Clothes, or answer the discussion questions. The ATBEQ was administered to both the experimental and the control groups after the experimental manipulation.

\section{Adapting the Film for an Organizational Behavior Class}

The film Enron: The Smartest Guys in the Room is based on the 2004 best-selling book The Smartest Guys in the Room: The Amazing Rise and Scandalous Fall of Enron by Fortune reporters Bethany McLean and Peter Elkin, a multidimensional study of one of the biggest business scandals in American history. The film draws from insider interviews and archival material to show how Enron, once the nation's seventh largest corporate entity, faked its bookkeeping to report profits that never existed. The corrupt and closely-guarded mismanagement by Enron executives is revealed through "creative" accounting concepts such as "Hypothetical Future Value" (a way of reaping fortunes based on false profit projections) and the use of offshore "shell" companies to hide the massive losses that eventually toppled the company (along with Arthur Andersen accounting firm) and left 20,000 employees jobless. Also revealed is the blind greed of Merrill Lynch, Arthur Andersen, and other corporations that ignored the impending doom in order to have a share of the pickings. The film utilizes popular music, cartoons like the Simpsons, news clips, and candid interviews to engage the 
viewer. Analogies are made to fairytales like "The Emperor's New Clothes" and "The Sorcerer's Apprentice", and historical events like the sinking of the Titanic, to help the viewer to better understand how Enron top management deceived the public. News clips from the infamous Stanley Milgram experiment, where $50 \%$ of subjects were willing to shock to the death, are used in an attempt to explain the corrupt behavior of the Enron traders.

While our main objective in using the film was to make students aware of ethical dilemmas in the workplace and engage them in discussion of their attitudes towards business ethics, the film also was used to help students to understand and apply to business the following concepts from the fields of Organizational Behavior and Social Psychology: Machiavellianism, social Darwinism, self-monitoring behavior, the distinction between ethical and non-ethical values, escalation of commitment, and charismatic leadership. Discussion questions (Appendix A) were developed for use with the film and are conveniently grouped to go with the subheadings used in the film (e.g. Kenny Boy, A Man with a Big Idea, Guys with Spikes, etc.). The run time for the film is 110 minutes. The discussion question headings are accompanied by approximate run times for each subheading to help instructors to know when to pause the film for discussion.

\section{Content Analysis of Qualitative Data}

Student written responses to questions about the film were coded and content analyzed using a qualitative analysis method recommended by Bogdan and Biklen (1982). Other researchers who describe similar methods for analyzing qualitative data include Becker (1970), Glaser and Strauss (1967), Lofland (1971) Schatzman and Strauss (1973), and Spradley (1980). We read through all student written responses, recording patterns and themes that seemed to emerge from the data, creating coding categories. Differences in the data were also noted and recorded resulting in the creation of separate coding categories or exceptions to the patterns and themes. The written responses were then analyzed a second time and coded by category, In accordance with prescribed qualitative research techniques, ideas and themes were "grounded" in the data, emerging through a careful search of the data for common themes and differences (Bogdan \& Biklen, p. 154).

\section{Results}

While random assignment of students to sections was not possible, it is important to ascertain the equivalence of the experimental and control groups prior to the teaching intervention. Table I contains descriptive statistics for the experimental and control groups for each post-test ATBEQ item, as well as $t$ statistics that measure the group mean differences. 


\section{Table I - Descriptive statistics for Attitudes Towards Business Ethics Questionnaire (ATBEQ) items and $t$ statistics}

\begin{tabular}{|c|c|c|c|c|c|}
\hline & \multicolumn{2}{|c|}{$\begin{array}{l}\text { Experimental } \\
\text { Group }(\mathrm{N}=29)\end{array}$} & \multicolumn{2}{|c|}{$\begin{array}{l}\text { Control Group } \\
\qquad(\mathrm{N}=26)\end{array}$} & \multirow[b]{2}{*}{$\mathrm{t}$} \\
\hline & Mean & Std. dev & Mean & Std. dev & \\
\hline 1. The only moral of business is making money. & 2.38 & 1.34 & 1.62 & .49 & 2.72 \\
\hline $\begin{array}{l}\text { 2. A person who is doing well in business does not have to worry } \\
\text { about money problems }\end{array}$ & 2.45 & .91 & 2.23 & .99 & .84 \\
\hline $\begin{array}{l}\text { 3. Every business person acts according to moral principles, } \\
\text { whether he/she is aware of it or not. }\end{array}$ & 1.86 & 1.02 & 2.50 & 1.36 & $-1.97^{*}$ \\
\hline 4. Act according to the law, and you can't go wrong morally. & 1.86 & .99 & 2.69 & 1.08 & $-2.96^{* *}$ \\
\hline $\begin{array}{l}\text { 5. Business decisions involve a realistic economic attitude and } \\
\text { not a moral philosophy. }\end{array}$ & 2.83 & 1.33 & 2.19 & .93 & 2.01 * \\
\hline 6. Moral values are irrelevant to the business world & 2.17 & 1.13 & 1.65 & .93 & 1.83 \\
\hline $\begin{array}{l}\text { 7. The lack of public confidence in the ethics of business people } \\
\text { is not justified. }\end{array}$ & 2.52 & .87 & 2.50 & .94 & .07 \\
\hline 8. "Business ethics" is a concept for public relations only. & 2.14 & 1.18 & 1.77 & .86 & 1.30 \\
\hline $\begin{array}{l}\text { 9. The business world today is not different from what it used to } \\
\text { be in the past. There is nothing new under the sun. }\end{array}$ & 2.00 & 1.13 & 1.58 & .90 & 1.51 \\
\hline $\begin{array}{l}\text { 10. Competitiveness and profitability are independent values } \\
\text { (existing on their own). }\end{array}$ & 2.90 & 1.20 & 2.31 & 1.08 & 1.89 \\
\hline $\begin{array}{l}\text { 11. Conditions of a free economy will serve best the needs of } \\
\text { society. Limiting competition can only hurt society and actually } \\
\text { violates basic natural laws. }\end{array}$ & 2.97 & 1.14 & 3.73 & .82 & $-2.80^{* \star}$ \\
\hline $\begin{array}{l}\text { 12. As a consumer when making a car insurance claim, I try to } \\
\text { get as much as possible regardless of the extent of the damage. }\end{array}$ & 3.45 & 1.08 & 3.08 & 1.32 & 1.14 \\
\hline $\begin{array}{l}\text { 13. As an employee, I take office supplies home; it doesn't hurt } \\
\text { anyone. }\end{array}$ & 2.59 & 1.32 & 2.23 & 1.03 & 1.10 \\
\hline 14. I view sick days as vacation days that I deserve. & 3.34 & 1.23 & 2.85 & 1.22 & 1.50 \\
\hline $\begin{array}{l}\text { 15. Employee wages should be determined according to the laws } \\
\text { of supply and demand. }\end{array}$ & 2.45 & 1.02 & 2.73 & 1.21 & -.93 \\
\hline $\begin{array}{l}\text { 16. For every decision in business the only question I ask is, "Will } \\
\text { it be profitable?" If yes-I will act according; if not, it is irrelevant } \\
\text { and a waste of time. }\end{array}$ & 2.72 & 1.16 & 2.56 & 1.19 & .51 \\
\hline $\begin{array}{l}\text { 17. In my grocery store every week I raise the price of a certain } \\
\text { product and mark it "on sale." There is nothing wrong with doing } \\
\text { this. }\end{array}$ & 2.04 & 1.10 & 1.96 & 1.18 & .23 \\
\hline 18. A good business person is a successful business person. & 3.00 & 1.38 & 3.00 & 1.26 & .00 \\
\hline 19. True morality is first and foremost self-interested. & 2.86 & 1.09 & 3.15 & 1.34 & -.88 \\
\hline 20. Self-sacrifice is immoral. & 2.79 & 1.11 & 2.19 & .89 & $2.18^{*}$ \\
\hline $\begin{array}{l}\text { 21. You can judge a person according to his work and his } \\
\text { dedication. }\end{array}$ & 3.24 & 1.15 & 3.31 & 1.22 & -.20 \\
\hline 22. You should not consume more than you produce. & 3.55 & .82 & 3.08 & 1.23 & 1.69 \\
\hline
\end{tabular}

- $p \leq .05^{* *} p \leq .01$ 
Compared to the control group, students in the experimental condition reported results that were significantly different ( $p \leq .05$ or lower) on six of the 22 ATBEQ items, more than would be expected by chance. Students that participated in the Enron class exercise agreed to a greater extent that the only moral of business is making money, business decisions involve economic factors but no moral philosophy, and that self sacrifice is immoral. On the other hand, students in the experimental group agreed to a lesser extent that business people act according to moral principles, business people that act lawfully cannot go wrong, and that conditions of a free society will best serve the needs of society. The experimental and control group did not differ with respect to ethic mindedness.

Table II reports the results of a principle components factor analysis of the 22 ATBEQ items. The objective of this analysis was to increase efficiency and parsimony of the ATBEQ. The principle components factor matrix with eigenvalues greater than or equal to 1 was rotated using the varimax rotation procedure (Rummel, 1970). In order to facilitate independence of factors and interpretability, variables with cross loadings greater than .30 were removed. A four factor solution resulted that accounted for $56 \%$ of the variance of the students' responses.

Table II

Rotated varimax factor analysis on Attitudes Towards Business Ethics Questionnaire (ATBEQ) Items

\begin{tabular}{lccc}
\hline Theoretical Factor label & Eigenvalues & $\%$ of Variance & Cumulative \% \\
\hline 1. Amoral Values & 3.18 & 24.517 & 24.51 \\
2. Self Serving Interests & 1.64 & 12.66 & 37.17 \\
3. Rule Bound Behavior & 1.31 & 10.12 & 47.30 \\
4. Personal Attributes & 1.18 & 9.12 & 56.42 \\
\hline
\end{tabular}

Table III contains the factors, the items, and the factor loadings. Four factors were identified: moral values, self serving interests, rule bound reasoning, and personal attributes. The first factor accounted for the greatest amount of variance $(24 \%)$. Factor scores were calculated using the regression method whereby factor scores have a mean of zero and variance equal to the squared multiple correlations between the estimated and true factor scores (SPSS, 2005). The experimental and control groups significantly differed with respect to the moral values $(t=2.26, p \leq .05)$ and rule bound reasoning factors $(t=-3.07, p \leq .01)$. 


\section{Table III}

Rotated factor loadings for the Attitudes Towards Business Ethics Questionnaire (ATBEQ)

\begin{tabular}{lc}
\hline Factor/ltems & Factor \\
loadings
\end{tabular}

\section{Amoral Values}

6. Moral values are irrelevant to the business world $\quad .76$

8. "Business ethics" is a concept for public relations only.

5. Business decisions involve a realistic economic attitude and not a moral $\quad .71$ philosophy.

1. The only moral of business is making money. $\quad .59$

16. For every decision in business the only question I ask is, "Will it be profitable?" If yes-I will act according; if not, it is irrelevant and a waste of $\quad .56$ time.

7. The lack of public confidence in the ethics of business people is not justified.

\section{Self Serving Interests}

13. As an employee, I take office supplies home; it doesn't hurt anyone.

14. I view sick days as vacation days that I deserve.

12. As a consumer when making a car insurance claim, I try to get as much as possible regardless of the extent of the damage.

\section{Rule Bound Reasoning}

22. You should not consume more than you produce.

4. Act according to the law, and you can't go wrong morally.

\section{Personal Attributes}

21. You can judge a person according to his work and his dedication.

15. Employee wages should be determined according to the laws of supply and demand.

The factor analysis used a principal component extraction method and a varimax rotation method with Kaiser Normalization. 


\section{Discussion}

The results gave partial support for the research hypothesis for 6 of the 22 ATBEQ items, and 2 of 4 factors identified in the factor analysis in that statistically significant differences emerged between the experimental group and the control group. However, rather than developing a more positive attitude towards the importance of ethical behavior in the workplace, students' attitudes were less idealistic and more cynical after the teaching intervention. The experimental group students reported that business was less moralistic than the control group (items 1 and 5), that following the law is no guarantee that one will be morally sound, and that business people do not naturally act according to moral principles.

The ATBEQ factor structure in the present study changed only slightly from that reported by Moore \& Radloff (1996). The first two factors, morale values and self serving interests, shared most of the same items and factor loadings in both studies. These two factors accounted for more variance than in previous studies, which may be due to a smaller ATBEQ used in the present study. The experimental group students also scored higher on the immoral value factor, indicating a belief that the business world is profit oriented at the expense of business ethics. The teaching intervention apparently left students with less optimistic attitudes about the ethical business world.

\section{Student Reaction to the Film}

Students reacted positively to the film and subsequent discussion, and watched the film with riveted attention. Many said that they were not very familiar with the extent of corruption at Enron prior to viewing the film. They expressed dismay at the complicity among the banks, Arthur Andersen, the Enron attorneys, and various Wall Street entities.

Qualitative analysis of student responses to the homework questions sheds some light on the quantitative results. For example, the film takes a negative view of deregulation. For example, when California deregulated its energy industry, Enron was able to manipulate the new regulations set by California to cause rolling black-outs. Enron asked the power plants it controlled to create artificial power outages, and used these shortages to speculate that the price of energy would go up. In other words, loop holes in the new regulations opened the door for Enron to manipulate the system to the detriment of the people of California. Students made the following comments when asked whether they thought deregulation was good or bad for the economy:

"I think deregulation is horrible. You need somebody watching somebody else at all times or people think they can get away with cheating the system."

"Deregulation is both good and bad for the economy. It helps consumers with prices, but employees and ethics often get compromised." 
"Kenneth Lay was an adamant supporter of deregulation, especially in terms of accounting standards. Deregulation without some government monitoring is a bad idea. Government intervention works to standardize procedures and prevent unethical practices."

"I think deregulation is bad for companies. I think that competition should drive business in the long run. However, the government still should be the watchdog and step in when needed. When there are no regulations for companies, what rules are they going to follow?"

"According to Adam Smith, the self-interest of the individual will make trade more efficient. The market is supposed to regulate itself. The price mechanism should protect shareholders by screening out bad companies. The example of Enron shows that this does not work all the time, at least in the short term. Sometimes the market can be misled and that makes some sort of regulation necessary."

The following student comments reveal that students developed a more cynical attitude towards business ethics:

"Ken Lay learned proper values growing up with a father who was a preacher. However, once he was at Enron he only cared about making money. That was the only thing that mattered to him. He was driven by non-ethical values."

"Ken Lay was so obsessed with money that he was willing to lie, cheat, and steal in order to make that happen for him."

"The executives at Enron were driven by greed and the will to succeed at all costs, even their personal ethics."

The above comments shed light on study results whereby the experimental group, after viewing the film, agreed to a greater extent that business decisions involve economic factors but no moral philosophy and agreed to a lesser extent that business people act according to moral principles.

However, while students developed a cynical attitude towards business and ethics, they did not seem to feel that business should be just about making profits:

"Skilling, as well as other CEOs should be held accountable to a higher standard."

"Ethical behavior is now very important for a company's public image. Jeff Skilling did not act in the interest of the Enron shareholders. As a good manager, he should have acted with the long term interests of the Enron shareholders in mind." 
Some of the most interesting discussion emerged when students were asked to compare the Enron scandal to the fairytale "The Emperors New Clothes:"

"The concept of swindling people is not new and this story [The Emperor's New Clothes] can be related to the case of Enron, and the corruption of its top executives. The two swindlers in the fairytale remind me of Skilling and Fastow who mislead the employees and the stock holders of the company into believing that profits existed when really there were none. This is similar to the Emperor's new clothes; the swindlers said they existed but in reality the Emperor was walking through the town bare naked."

"The story "The Emperor's New Clothes" and the Enron scandal show that it is easier to agree with something that is wrong than it is to expose something you know to be wrong."

"The swindlers in the story talk about how beautiful the patterns in the fictitious cloth are. This is just like the Enron traders and management saying that they are earning huge profits when they are in reality losing money. The weavers never made anything for the emperor and Enron wasn't making any real profits. Both the weavers and Enron management created their own reality when it came to both clothes and profits."

"At the end of the story, a child yells out from the crowd that the Emperor doesn't have any clothes on. I think this is just like the Fortune reporter who was the first one to ask the question 'how was Enron making its money?' Sometimes it takes someone with real guts, or who doesn't know any better, to speak up and reveal unethical behavior."

\section{Study Limitations}

Prior to addressing implications of these findings, we address study limitations and future research below. First, the researchers did not randomly assign students to the experimental and control groups. As in most academic settings, individual student schedules made this randomization impossible. Second, the sample size was small. Third, one instructor taught both the experimental and control group. While this may have minimized any kind of instructor effect, the instructor was not blind to the specific study hypothesis. Fourth, the extent that students were biased against Enron prior to the film is unknown. The impact of the bias on attitudes toward business ethics was likely equal across the experimental and control groups prior to the study. Fifth, while we did find a significant change in some of the attitudes held by the experimental group, we have no way of knowing whether there was a corresponding change in moral development. Did students after the Enron intervention merely gain a more cynical view of the business world-a view where making money is more important than ethics and morality? After viewing the film, do they feel that it is appropriate for businesses to make money at the expense of sacrificing ethics and morality? Anecdotally, our qualitative analysis of student responses to the film suggests students felt that businesses and 
business executives should be held to a higher standard. However, this requires further testing.

\section{Conclusion}

\section{Study Implications}

Quantitative and qualitative data supported the study hypothesis that students' attitudes towards business ethics were influenced by the teaching intervention; however, not in the direction we anticipated. Students may have developed more realistic (and perhaps more cynical) views of the business world. Additionally, this study contributes to the business ethics education literature by employing an experimental design utilizing control and experimental groups. Unlike previous research where the control group was a different class entirely, this research compared students in different sections of the same course taught on the same day by the same instructor. This research also provides a revised, more efficient version of the ATBEQ. Discussion questions corresponding to each subheading of the film are provided (Appendix A).

While the results of this research imply that use of the Enron film can have a significant impact on student attitudes towards business ethics, what message did the film give students? Was the message that the reality of the workplace is to make money at the expense of ethics and morality? Koehn (2005) contends that that is the message students and employees seem to be hearing with the increased reporting in the media of scandalous corporate behavior-that today's workplace is all about selfishness and greed.

Our goal in showing the film was to bring about a positive change in our students' attitudes towards business ethics. Did we instead establish an even greater gap between what is right and what it takes to get ahead in the business world? Revealing an even greater congruence between ethical behavior and profitability may result in students feeling that ethical behavior has no place in the business world. While the post-test ATBEQ results seem to indicate that students developed a more realistic, less optimistic view of the business world, our qualitative analysis of student responses indicate that students may not feel that the state of the American workplace as portrayed by the Enron scandal is an appropriate one. The following comment is an example of student comments to this effect that emerged from discussions following the viewing of the film:

"It is just not enough to act in the interest of the shareholders because one needs to also act in accordance with society's ethics and values. If you are going to behave unethically and break the law then you are not acting in anyone's best interest. In the long run making money at the cost of ethical behavior did not benefit any of the Enron stakeholders because the Enron stock plummeted when the truth came out." 


\section{Future Research}

Future research should continue to investigate the impact of educational interventions on student's awareness of and attitudes towards business ethics. Specifically, we recommend research to answer the following questions:

- What impact does use of the Enron film have on students' moral reasoning? Students' context specific moral reasoning and general moral reasoning could be assessed before and after the Enron film intervention using Thorne's Accounting Ethical Dilemma Instrument and Rest's Defining Issues Test respectively.

- What impact does use of the Enron film have on increasing student awareness of ethical issues? This question could be assessed using the same methodology as Gautschi and Jones (1998) whereby students in experimental and control conditions are asked to read vignettes about corporate culture with raters "grading" the student responses by counting the number of ethical issues listed by each student.

- This research employed only one intervention over a short period of time and utilized a small sample. Attitudes towards business ethics is multidimensional in that it may be comprised of intrapersonal, interpersonal, cultural, and legal dimensions. It is not clear from our research whether the students' change in attitudes represents a short term heightened effect or a long term effect. From an outcomes assessment perspective, future research should investigate the dimensionality of ethics, employ multiple interventions, and measure outcomes over a longer time period.

- Does the age of the student have an effect on the impact of ethical interventions in the classroom? The students in the Organizational Behavior classes assessed by this research were juniors and seniors. What impact would the study have on attitudes towards business ethics if the Enron film and discussion questions were administered to first-year business students?

- To what extent do students make a correlation between the influence of personal ethics on the cultivation of business ethics? In other words, might they take into account Ken Lay's and Jeff Skilling's personal value systems, or lack thereof, as drivers of the larger organizational culture, from an ethical standpoint? To what extent do students feel employees, at the lower organizational levels, are responsible for helping to correct unethical behavior before it is too late?

- To reduce the ambiguity as to what the ATBEQ measures we propose research to ascertain the following:

1. Does the questionnaire assess respondents' attitudes towards the importance of ethical behavior in the workplace, or does it instead assess respondents' observations of the reality of the workplace? For example, 
does agreement with the statement "Business decisions involve a realistic economic attitude and not a moral philosophy" signify respondents feel that morality has no place in the workplace or are respondents reflecting on what they feel is the reality of the workplace given recent corporate scandals?

2. Does the questionnaire measure students' personal ethical beliefs as measured by how they would behave in certain hypothetical situations? For example, does the item, "As a consumer when making a car insurance claim, I try to get as much as possible regardless of the extent of the damage", measure students' beliefs by way of intended behavior? Alternatively, does the questionnaire measure students' beliefs about the state of business ethics as stated in (1) above?

- The Enron film is a highly engaging, vivid portrayal of corporate greed and immoral behavior in the workplace. Would the use of a less engaging film have the same impact on student attitudes towards business ethics? The Enron film takes a negative view of behavior in the workplace, portraying it as immoral and unethical. What might happen if students were shown a film with a more positive message, one depicting a company acting in an ethical, socially responsible manner? What would be the impact on student attitudes towards business ethics?

In conclusion, the results of this study suggest that the use of the Enron film can have a significant impact on students' attitudes towards business ethics. Organizational ethics are a growing concern and there is an increasing emphasis on including business ethics in business school curricula. Teaching interventions such as those investigated in this study are, therefore, important contributions to pedagogical research and curriculum design.

\section{References}

Blanchard, P.N. \& Thacker, J.W. (2007). Effective training: Systems, strategies, and practices. New Jersey: Prentice Hall.

Becker, H. S. (1970). Sociological work. Chicago: Aldine.

Bogdan, R.C. \& Biklen, S.K. (1982). Qualitative research for education: An introduction to theory and methods. Boston: Allyn and Bacon.

Brown, K.M. (1994). Using role play to integrate ethics into the business curriculum: A financial management example. Journal of Business Ethics, 13, 105-110.

Callahan, D. (1980). Goals in teaching of ethics. In D. Callahan \& S. Bok (eds.), Ethics in higher education. New York: Plenum Press. 
Earley, C.E. \& Kelly, P.T. (2004). A note on ethics educational interventions in an undergraduate auditing course: Is there an Enron effect? Issues in Accounting Education, 19(1), 53-71.

Enron: The smartest guys in the room. (2005). Magnolia Studios. Available on DVD at www.amazon.com.

Faust, J.E., Ginno, A., Laherty, J., \& Manuel, K. (2001). Teaching information literacy to generation y: Tested strategies for reaching the headphone-wearing, itchy mouse-fingered and frequently paged. Poster session, ACRL $10^{\text {th }}$ National Conference, Denver, CO, March 15-18.

Gautschi, III, F.H. \& Jones, T.M. (1998). Enhancing the ability of business students to recognize ethical issues: An empirical assessment of the effectiveness of a course in business ethics. Journal of Business Ethics, 17, 205-216.

Glazer, B. \& Strauss, A. (1967). The discovery of grounded theory: Strategies for qualitative research. Chicago: Aldine.

Haywood, M.E., McMullen, D.A. \& Wygal, D.E. (2004). Using games to enhance student understanding of professional and ethical responsibilities. Issues in Accounting Education, 19(1), 85-99.

Honeycutt, E., Jr.; McCarty, T.; \& Howe, V. (1993). Sales technology implications: Self paced video enhanced training: A case study. Journal of Personal Selling and Sales Management, 13(1), 73-79.

Kidwell, Jr., R.E. \& Kochanowski, S.M. (2005). The morality of employee theft: Teaching about ethics and deviant behavior in the workplace. Journal of Management Education, 29, 135-152.

King, P.M. \& Mayhew, M.J. (2002). Moral judgment development in higher education: Insights from the Defining Issues Test. Journal of Moral Education, 31(3), 247270 .

Koehn, D. (2005). Transforming our students: Teaching business ethics post-Enron. Business Ethics Quarterly, 15(1), 137-151.

Lofland, J. (1971). Analyzing social settings. Belmont, CA., Wadsworth.

MacFarlane, B. (2001). Developing reflective students: Evaluating the benefits of learning logs within a business ethics program. Teaching Business Ethics, 5, 375-387.

Magnolia Films (2005). Enron: The smartest guys in the room. HDNET Films video. 
McDonald, G.M. (2004). A case example: Integrating ethics into the academic business curriculum. Journal of Business Ethics, 54, 371-384.

McDonald, G.M. \& Donleavy, G.D. (1995). Objections to the teaching of business ethics. Journal of Business Ethics, 14, 839-853.

McLean, B. \& Elkin, P. (2004). The smartest guys in the room: The amazing rise and scandalous fall of Enron. New York: Penguin Books.

McPhail, K. J. (2002). Using porridge to teach business ethics: Reflections on a visit to Scotland's most notorious prison and some thoughts on the importance of location in teaching business ethics. Teaching Business Ethics, 6(3), 355-369.

Molyneaux, D. (2004). After Andersen: An experience of integrating ethics into undergraduate accountancy education. Journal of Business Ethics, 54, 385-398.

Moore, R.S. \& Radloff, S.E. (1996). Attitudes towards business ethics held by South African students. Journal of Business Ethics, 15(8), 863-869.

Morse, J. (1999). Who is the ethics expert? The original footnote to Plato. Business Ethics Quarterly, 9(4), 693-697.

Nisbett, K.P. \& Eagley, A.H. (1980). Human inference: Strategies and short-comings of social judgment. Englewood Cliffs, N.J.: Prentice-Hall.

Pascarella, E. \& Terenzini, P. (1991). How college affects students. San Francisco, CA: Jossey-Bass.

Penn, Jr., W.Y. \& Collier, B.D. (1985). Current research in moral development as a decision support system. Journal of Business Ethics, 4(2), 131-138.

Petrecca, L. (2002, September 23). Conduct enters the curriculum: Law, business schools respond to scandals, revamp. Crain's New York business.

Power, C. \& Vogel, D. (1980, Spring). Ethics in the education of business managers. Sloan Management Revie, 39-49.

Preble, J.F. \& Reichel, A. (1988). Attitudes towards business ethics of future managers in the U.S. and Israel. Journal of Business Ethics, 7, 941-949.

Rest, J.R. (1979). Development in judging moral issues. Minneapolis, MN: University of Minnesota Press.

Robinson, S. \& Bennett, R. (1995). A typology of deviant workplace behaviors: A multidimensional scaling study. Academy of Management Journal, 38, 555-572. 
Rummel, R.J. (1970). Applied factor analysis. Evanston: Northwestern University Press.

Schatzman, L. \& Strauss, A. (1973). Field research. Englewood Cliffs, N.J.: PrenticeHall.

Schwartz, R.H., Kassem, S., \& Ludwig, D. 1991. The role of business schools in managing the incongruence between doing what is right and doing what is takes to get ahead. Journal of Business Ethics, 10, 465-469.

Sims, R.R. \& Sims, S.J. (1991). Increasing applied business ethics courses in business school curricula. Journal of Business Ethics, 10(3), 211-219.

Small, M.W. (1992). Attitudes towards business ethics held by Western Australian students: A comparative study. Journal of Business Ethics, 11, 745-752.

Spradley, J. P. (1980). Participant observation. New York: Holt, Rinehart, \& Winston.

Stape, A.L. (2002). Ethics: Area business schools are not rushing to add courses on ethical behavior as a result of the Enron scandal. The Providence Journal (April 7).

Stevens, E. (1979). Business ethics. Paulist Press, New York.

Statistic Package for the Social Sciences, version 14.0.1, November 2005.

Thorne, L. (2000). The development of two measures to assess accountants' prescriptive and deliberative moral reasoning. Behavioral Research in Accounting, 12, 139-169.

Thorne, L. \& Hartwick, J. (2001). The directional effects of discussion on auditors' moral reasoning. Contemporary Accounting Research, 18(2), 337-361.

Vogel, D. (1980). Business ethics: New perspectives on old problems. California Management Review, 33, 101-117.

Williams, S.D. \& Dewett, T. (2005). Yes, you can teach business ethics: A review and research agenda. Journal of Leadership and Organizational Studies, 12(2), 109120. 


\section{Appendix A \\ Enron: The Smartest Guys in the Room \\ Discussion Guide}

The following questions have been developed for use with "Enron: The Smartest Guys in the Room." The questions have been grouped to go with corresponding subtitles used in the film. Times are approximations.

Introduction /Kenny Boy (16 minutes)

1. What is the significance of the Billie Holiday song "God Bless the Child" used in the beginning of the film?

Mama may have

Papa may have

But God bless the child that's got his own, that's got his own

The strong gets more while the weak one's fade

Empty pockets don't ever make the grade

Mama may have

Papa may have

But God bless the child that's got his own, that's got his own

Money you got lots of friends

Crowding round the door...

In what way can the message of the song be related to Ken Lay's childhood?

values and subsequent fall from grace?

What values did Ken Lay learn from his childhood? Which values took precedent?

while Lay was at Enron?

2. Jeff Skilling states that he was only acting in the interest of the shareholders. Did Skilling's unethical behavior benefit the shareholders? Why or why not?

3. Is deregulation good or bad for the economy? Explain.

4. In the beginning of the film, Cliff Baxter says "They're calling us child molesters. That will never wash off." What are Baxter's primary concerns?

Ken Lay is said to have "wrapped himself in the cloak of moral rectitude." What is meant by this description of Lay?

5. Why didn't the company learn from the Valhalla scandal? Why didn't Lay take action and punish the perpetrators? What values took precedence-ethical or non-ethical values (see p. 7 for a definition of ethical and non-ethical values)?

A Man with a Big Idea (11 minutes)

6. Amanda Martin describes Skilling as "A leader who imbued us with a sense of self-confidence, that if we were smart ... you can't imagine how proud we all were to be there. Making money." What are the characteristics of charismatic leadership (see definitions, p. 7) and in what way did Skilling embody them? 
7. Explain the concept and rationale behind mark to market accounting. Why do you suppose the SEC allowed Enron to engage in mark to market accounting?

8. Skilling's favorite book is entitled The Selfish Gene. The book contends that human nature is steered by greed and competition in the service of passing on genes. Is money the primary thing that motivates people? Explain.

9. Describe the Enron corporate culture. Explain how the following reinforced the Enron corporate culture and the notion of "survival of the fittest?"

- Rank and yank

- Executives engaging in extreme sports

Guys with Spikes (5 minutes)

10. What motivated Lou Pai?

11. One of the individuals interviewed in the film states: "You wanted to be the most popular guy on Wall Street and you would do whatever you had to do to stay there." She says there existed a "high school mythology" at Enron. What does she mean? How did Lay's and Skilling's backgrounds feed into their desire to belong and to be seen as successful and popular? How did the quest to belong interfere with behaving ethically?

\section{Love me, Love me/Love for Sale (5 minutes)}

12. Why were the Wall Street analysts willing to believe anything about Enron? What factors perpetuated the Enron myth? Why were the warnings ignored?

13. In what way is the Enron scandal similar to what happened to the Titanic?

Emperor has no Clothes (5 minutes)

Read "The Emperor's New Clothes" and answer the following question:

14. How does the moral of the fairytale "The Emperor's New Clothes" apply to the Enron scandal? Who is the emperor? Who represents the boy who declares "the emperor has no clothes?" In what way are the emperor's "new clothes" analogous to the Enron's "black box" financials? Why was Wall Street willing to take it on faith that Enron was making money?

15. What is meant by the term "escalation of commitment?" In what way did escalation of commitment occur at Enron?

The Sorcerer's Apprentice (8 minutes)

16. How did Enron use Andy Fastow and how did Fastow use Enron? What motivated Andy Fastow?

Useful Idiots (2 minutes)

17. Who were the "useful idiots?"

18. Why didn't the investment bankers, the U.S. financial institutions, and Arthur Anderson act as "checks and balances" to put a stop to unethical practices at Enron? What values took precedence? 
Ask why, Asshole (3 minutes)

19. What were the first signs that the Enron façade was cracking? Is unethical behavior stressful?

Kal-ee-for-nyah (20 minutes)

20. In what way did deregulation contribute to the California power shortage? Was the problem deregulation and free markets or unethical manipulation of the rules? Can deregulation work when the entity being traded freely is electricity or does electricity as the "lifeblood of the economy" need to be regulated? Is a free market expensive to consumers? Why or why not?

21. What was the primary value operating among the traders? What was the Enron definition of a "good trader?"

22. Consider the following statement by Bethany McLean: "The Enron traders never seemed to step back and say 'Wait, is what we're doing ethical, is it in our best long term interest? Does it help us if we totally rape California? Does that advance our goals of nationwide deregulation?' Instead they sought out every loop hole they could to profit from California's misery." Does unethical behavior in the long run benefit a company?

23. One of the traders who was interviewed states he was never comfortable on the trading floor of Enron, and that he didn't ask questions because he didn't want it confirmed that what he was doing was unethical. Were the traders at Enron inherently evil or can normal people be led to do bad things? Why did the traders do what they did? What circumstances might cause normal, ethical people to lose their moral compasses?

24. How did the Enron corporate culture of "survival of the fittest" contribute to the traders' behavior?

25. In the Stanley Milgram experiment, why were $50 \%$ of the suspects willing to shock to the death? In what way does Milgram's experiment help to explain the behavior of the Enron traders?

The Ship is Sinking/Jeff has Left the Building (20-25 minutes)

26. In what ways do the following personal styles of behavior characterize Jeff Skilling, Andy Fastow, and Ken Lay?

- Machiavellianism - a personal style towards others characterized by (1) the use of guile and deceit in interpersonal relationships, (2) a cynical view of the nature of other people, and (3) a lack of concern with conventional morality. A person who scores high on a test to measure Machiavellianism probably would agree that the best way to handle people is to tell them what they want to hear, and never tell anyone you did something unless it is useful to do so.

- Self-Monitoring - the extent to which a person observes their own selfexpressive behavior and adapts it to the demands of the situation. 
Individuals high on self-monitoring are thought to regulate their expressive self-presentation for the sake of desired public appearances.

27. What does whistle-blower Sherron Watkins mean when she says companies survive when they come clean? Why didn't Watkins initially report Enron to the authorities?

28. Why did Wall Street wait until the collapse of Enron to investigate the company? Why didn't the SEC investigate Enron earlier? Why was there complicity across the board among the banks, Arthur Anderson, and the Enron attorneys (Vincent \& Elkins)?

Did the financial institutions, Arthur Anderson, and the attorneys contribute to unethical behavior at Enron? Was there a diffusion of responsibility whereby the executives at Enron told themselves that their behavior was okay because the bankers, Arthur Anderson, and the lawyers knew what they were doing?

29. Why does Lay continue to perpetuate the myth that the company is doing well? Ken Lay ultimately to blame? The film suggests that Lay was either a crook or an idiot? Which term do you think best describes Lay? Explain.

30. Why is the Simpsons cartoon a good metaphor for what happened at Enron?

31 .Who were the victims of the Enron scandal? The words "molesters" and "rapists" have been used to describe the executives at Enron. Are these words accurate descriptions? Why or why not?

32. A priest at the end of the film contends that the pursuit of money can cause one to lose one's soul? Is he right in the case of the principals at Enron? Explain.

33. Is Enron an aberration? Have companies through history always put money before ethics? Could another scandal of this magnitude happen in the future? Explain.

34. Is the primary obligation of business to make money for shareholders? Is obeying the law more important than making money, or is it okay to bend the rules a little as long as one doesn't get caught? Or no o ne gets hurt? Are ethics and the law one in the same? Can something be unethical even though it is legal?

35. Does hard work (effort) always get you ahead in business? Why or why not?

36. Consider the following values:

- Hard work

- Dedication

- Greed, making money

- Thrift, efficiency

- Self-sacrifice

- Truth

- Personal responsibility

- Sense of belonging

- Obeying the law

How are these values related? Not related? Which of the above values could be considered ethical values? Non-ethical values? Which of the above values should take precedent in an ethical society? In business? 


\section{Definitions:}

- Machiavellianism - a personal style towards others characterized by (1) the use of guile and deceit in interpersonal relationships, (2) a cynical view of the nature of other people, and (3) a lack of concern with conventional morality. A person who scores high on a test to measure Machiavellianism probably would agree that the best way to handle people is to tell them what they want to hear, and never tell anyone you did something unless it is useful to do so.

- Self-Monitoring - the extent to which a person observes their own selfexpressive behavior and adapts it to the demands of the situation. Individuals high on self-monitoring are thought to regulate their expressive self-presentation for the sake of desired public appearances ....

- Ethical values- honesty, faithfulness, trustworthiness, helpfulness

- Non-ethical values - money, fame, a comfortable life, ethical values should take precedence

- Escalation of commitment - an increased commitment to a previous decision in spite of negative information

- Charismatic leadership - charismatic leaders concern themselves with developing a vision of what could be, discovering or creating opportunities, and increasing employees' desire to control their own behaviors. In addition to creating a vision, charismatic leaders instill self-confidence in their followers that they can achieve that vision. Followers of charismatic leaders identify with and are inspired by charismatic leaders in the hope that they will succeed. Charismatic leaders relish risk and emotionally put themselves on the line, working on hearts as well as minds.

\section{Ethics Triangles}

Laws - determined through the political process and the basic minimal standard that each citizen should adhere to.

Business ethics - a set of moral rules and obligations that are set by professional organizations overseeing the industry and/or by business organizations themselves. Business ethics should never be below the law; therefore they are set above the standard of the law.

Personal ethics - personal ethics of each individual can be different and beyond those set by businesses.

Where does making money fit into the ethics triangle? Making money is a non-ethical value and should not take precedence over obeying the law and adhering to business and personal ethical standards. However, studies show that in the long run, firms that behave ethically and demonstrate social responsibility do as well if not better financially than firms that do not. 


\section{Appendix B Attitudes towards Business Ethics Questionnaire}

Part 1 -Reflect on the following statements about business attitudes in questions 1-22. Indicate your position regarding each statement by coloring in the corresponding circle on the scantron that is closest to your view. Your answers are confidential.

$1=$ Strongly disagree, $2=($ Disagree $), 3=($ Not sure $), 4=($ Agree $), 5=($ Strongly agree $)$.

1. The only moral of business is making money.

2. A person who is doing well in business does not have to worry about money problems.

3. Every business person acts according to moral principles, whether he/she is aware of it or not.

4. Act according to the law, and you can't go wrong morally.

5. Business decisions involve a realistic economic attitude and not a moral philosophy.

6. Moral values are irrelevant to the business world.

7. The lack of public confidence in the ethics of business people is not justified.

8. "Business ethics" is a concept for public relations only.

9. The business world today is not different from what it used to be in the past. There is nothing new under the sun.

10. Competitiveness and profitability are independent values (existing on their own).

11. Conditions of a free economy will serve best the needs of society. Limiting competition can only hurt society and actually violates basic natural laws.

12. As a consumer when making a car insurance claim, I try to get as much as possible regardless of the extent of the damage.

13. As an employee, I take office supplies home; it doesn't hurt anyone.

14. I view sick days as vacation days that I deserve.

15. Employee wages should be determined according to the laws of supply and demand.

16. For every decision in business the only question I ask is, "Will it be profitable?" If yes-I will act according; if not, it is irrelevant and a waste of time.

17. In my grocery store every week I raise the price of a certain product and mark it "on sale." There is nothing wrong with doing this.

18. A good business person is a successful business person.

19. True morality is first and foremost selfinterested.

20. Self-sacrifice is immoral.

21. You can judge a person according to his work and his dedication.

22. You should not consume more than you produce. 
Part 2 -Directions: please answer the following questions about yourself. Color in the corresponding circle on the scantron.

23. My age range is
a. $15-20$
b. $21-25$
c. $26-30$
d. $31-35$
e. Over 35

24. I am completing this questionnaire in my
a. HRM 385 - 9:10 section

b. HRM $385-10: 20$ section

25. My gender is
a. male
b. female

26. My major is
a. Business Administration/Management/Marketing
b. Human Resource Management
c. Wellness Management
d. Accounting/Finance
e. Other

27. Do you practice religion?
a. Never
b. Sometimes
c. Always

28. All things considered, I would describe myself an ethically minded sort of person?
a. Not at all true
b. Somewhat true
c. Totally true 


\section{Appendix C - Values and Business Ethics Lecture Outline}

- Values

- Basic convictions that a specific mode of conduct or end-state of existence is personally or socially preferable to an opposite mode of conduct or endstate of existence

- Judgmental - what is right, good, desirable

- Stable and enduring

- Values influence attitudes and behavior

- Rokeach Value Survey

- Terminal values

- End states of existence

- Goals to achieve over a lifetime

- Examples: comfortable life, sense of accomplishment, freedom, happiness, self-respect

- Instrumental values

- Preferable modes of behavior

- Means of achieving terminal values

- Examples: ambition, cleanliness, helpfulness, self-control, honesty, cheerfulness

- Values and Business Ethics

- Ethical versus non-ethical values

- Ethical values - honesty, faithfulness, trus tworthiness, helpfulness

- Non-ethical values - money, fame, a comfortable life

- Ethical values should take preference over non-ethical values

- Businesses that perform ethically do as well or better than businesses that do not 